\title{
Opportunities for winter prescribed burning in mixed conifer plantations of the Sierra Nevada
}

\author{
Robert A. York ${ }^{1 *}$, Jacob Levine ${ }^{2}$, Kane Russell ${ }^{1}$ and Joseph Restaino ${ }^{3}$
}

\begin{abstract}
Background: Young, planted forests are particularly vulnerable to wildfire. High severity effects in planted forests translate to the loss of previous reforestation investments and the loss of future ecosystem service gains. We conducted prescribed burns in three $\sim 35$-year-old mixed conifer plantations that had previously been masticated and thinned during February in order to demonstrate the effectiveness of winter burning, which is not common in the Sierra Nevada, California.

Results: On average, $59 \%$ of fine fuels were consumed and the fires reduced shrub cover by $94 \%$. The average percent of crown volume that was damaged was 25\%, with no mortality observed in overstory trees 1 year following the fires. A plot level analysis of the factors of fire effects did not find strong predictors of fuel consumption. Shrub cover was reduced dramatically, regardless of the specific structure that existed in plots. We found a positive relationship between crown damage and the two variables of Pinus ponderosa relative basal area and shrub cover. But these were not particularly strong predictors. An analysis of the weather conditions that have occurred at this site over the past 20 years indicated that there have consistently been opportunities to conduct winter burns. On average, 12 days per winter were feasible for burning using our criteria. Windows of time are short, typically 1 or 2 days, and may occur at any time during the winter season.

Conclusions: This study demonstrates that winter burning can be an important piece of broader strategies to reduce wildfire severity in the Sierra Nevada. Preparing forest structures so that they can be more feasible to burn and also preparing burn programs so that they can be nimble enough to burn opportunistically during short windows are key strategies. Both small landowners and large agencies may be able to explore winter burning opportunities to reduce wildfire severity.
\end{abstract}

Keywords: Pyrosilviculture, Plantations, Winter burning, Fuel consumption, Canopy damage, Controlled burning, Prescribed fire

\footnotetext{
* Correspondence: ryork@berkeley.edu

${ }^{1}$ Department of Environmental Science, Policy, and Management, UC Berkeley, Berkeley, USA

Full list of author information is available at the end of the article
}

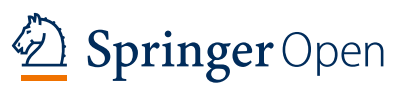

(c) The Author(s). 2021 Open Access This article is licensed under a Creative Commons Attribution 4.0 International License, which permits use, sharing, adaptation, distribution and reproduction in any medium or format, as long as you give appropriate credit to the original author(s) and the source, provide a link to the Creative Commons licence, and indicate if changes were made. The images or other third party material in this article are included in the article's Creative Commons licence, unless indicated otherwise in a credit line to the material. If material is not included in the article's Creative Commons licence and your intended use is not permitted by statutory regulation or exceeds the permitted use, you will need to obtain permission directly from the copyright holder. To view a copy of this licence, visit http://creativecommons.org/licenses/by/4.0/. 


\section{Resumen}

Antecedentes: Las plantaciones jóvenes son particularmente vulnerables a los incendios. Los efectos de una alta severidad del fuego en plantaciones jóvenes se convierten en pérdidas de las inversiones previas en la reforestación y también en pérdidas de ganancias futuras en los servicios ecosistémicos. Condujimos quemas prescriptas en tres plantaciones de coníferas mixtas de aproximadamente 33 años de edad que había sido previamente raleadas y trituradas. La quema se realizó durante febrero para demostrar la efectividad de las quemas de invierno, lo cual no es común en las Sierras Nevadas de California, EEUU.

Resultados: En promedio, el 59\% de los combustibles finos fueron consumidos y las quemas redujeron la cobertura de arbustos en un 94\%. El porcentaje promedio del volumen de copa que fue dañado alcanzó el 25\%, sin mortalidad observada en los doseles de los árboles un año después de la quema. Un análisis a nivel parcela de los factores que incidieron en los efectos del fuego no mostraron fuertes predicciones en el consumo de combustibles. La cobertura de arbustos fue reducida dramáticamente, independientemente de la estructura existente en cada parcela. Encontramos una relación positiva entre el daño a las copas y dos variables de Pinus ponderosa como área basal relativa y cobertura de arbustos. Desde luego, ambos no fueron predictores importantes. Un análisis de las condiciones ambientales que ocurrieron en este sitio en los últimos 20 años indicó que había habido consistentemente períodos en los cuales se hubiesen podido realizar quemas prescriptas. En promedio, en 12 días por cada invierno hubiese sido posible realizar estas quemas de acuerdo a nuestros criterios. Dentro de ellos, las ventanas de prescripción en el tiempo fueron cortas, típicamente de uno a dos días, pudiendo presentarse en cualquier momento durante el invierno.

Conclusiones: Este estudio demuestra que las quemas de invierno pueden ser una parte importante de estrategias más amplias para reducir la severidad de los incendios en las Sierras Nevadas. El preparar las estructuras forestales de manera que puedan ser más factibles de quemar y a la vez preparar programas de quema que puedan ser lo suficientemente ágiles como para quemar convenientemente durante los períodos cortos en los que las ventanas de oportunidad lo permiten, se tornan en estrategias claves. Tanto los pequeños propietarios como las grandes agencias de administración de recursos pueden explorar las quemas de invierno para reducir la severidad de los incendios.

\section{Abbreviations}

AR: $\quad$ Autoregressive

BFRS: Blodgett Forest Research Station

CARB: California Air Resources Board

LASSO: Least absolute shrinkage and selection operator

LOOVC: Leave-one-out cross-validation

PCVS: Percent crown volume scorch

RAWS: Remote-automated weather station

US: $\quad$ United States

USDA: United States Department of Agriculture

\section{Background}

In California, approximately 1 million hectares of mixed conifer forestland is less than 50 years old, with more than half of that actively managed in plantations (USDA 2021). As the extent and severity of wildfires increase, the degree to which mixed conifer plantations are exposed to wildfire will also increase (North et al. 2019). As such, the development and maintenance of plantation stand structures that can withstand wildfires so that basic management objectives are still met is of increasing importance.
Related lines of evidence from modeling, structural attributes, and empirical data suggest that fire severity may be higher in western US conifer plantations compared to mature forests. Wildfire behavior modeling predicts exceptionally high fireline intensities and rates of spread in plantations, resulting in the prediction of primarily crown fire behavior during high fire hazard weather conditions (Stephens and Moghaddas 2005a). Traditionally, plantations have been characterized by homogenous canopies, moderate or high shrub components, low height to crown bases, and high densities of small trees-structural components that have long been understood to make them vulnerable to fire (e.g., Kobziar et al. 2009). More recently, empirical evidence from post-wildfire assessments in productive mixed conifer forests have found increased severities in plantations compared to mature forests (Thompson et al. 2011; Zald and Dunn 2018; Levine et al. In Press). Rather than reducing even-aged management as a response to these results, most suggest that plantations be managed in specific ways to mitigate fire severity. In other words, it is not the silvicultural practice of even-aged management that inherently makes plantations vulnerable, but the lack of cultural practices designed to make them less 
vulnerable as they develop. These include site preparation to reduce early fuel loads (Lyons-Tinsley and Peterson 2012), altering planting density (North et al. 2019), and fuel treatments during early stand development (Zald and Dunn 2018). High-severity wildfires have created large areas of early seral conditions, causing multiple landowner types to consider options for young stand management regardless of whether or not they previously practiced even-aged regeneration.

Following wildfires or even-aged regeneration harvests, landowners who want to quickly establish tree dominated structures have decades of timber-focused reforestation research to draw upon (Baldwin et al. In Press). By the time a mature forest structure develops, numerous treatments may have occurred. Treatment costs can add up to several thousand dollars per hectare, with future revenue possible only after several decades (Stewart et al. In Press). This investment is at risk of total loss if a wildfire occurs before trees are sufficiently large to develop fire-resistant properties, or if surface fuels are not maintained at low levels throughout stand development. The risk of loss occurs regardless of whether investments were made for timber or any other objective that prioritizes the rapid recruitment of large, vigorous trees. Thinning via mechanical tree removal is the primary treatment used to increase tree vigor in young stands, but it does not address concerns with surface fuel accumulations. In fact, it can increase rather than decrease surface fuels (Hartsough et al. 2008; Stephens and York 2017). Whole tree yarding of biomass helps reduce activity fuel increases from thinning treatments (Han et al. 2009), yet it does not counter surface fuel deposition inherent to developing stands where leaf area accumulates rapidly. Attention to the long-term feedbacks between treatments and expected fire behavior is central to the "ecology of fuels" concept that has been applied in southeastern US forests (Mitchell et al. 2009) but is less developed in dry western US forests.

Low-intensity prescribed fire is the lowest-cost treatment available for reducing surface fuels in both mature (Hartsough et al. 2008) and young forests (Stewart et al. In Press). Prescribed fire may enhance what is thought to be resilience in plantations, but neither the feasibility nor effects are well studied (North et al. 2019). The predominant strategy for managing for timber growth is to avoid fire, intentional or not, and hope to achieve a large-tree structure before the next wildfire. This assumption is arguably no longer valid, as the probability of a high severity fire occurring in a developing stand has increased across all ownership types despite increasing fire suppression efforts (Starrs et al. 2018). Thus, the use of fire in plantations and the protection of long-term economic investments are no longer mutually exclusive. Yet, any benefit to prescribed fire in plantations will inevitably be weighed against negative impacts to tree growth and survival. Despite the benefits of prescribed fire, its operational bluntness is in stark contrast to the high precision of other treatments to which managers are accustomed. Using prescribed fire during dry conditions in the early fall (York et al. 2021) or when terminal buds of trees are vulnerable in the spring during active growth (Agee 1993; Bellows et al. 2016) may result in levels of fire-related damage or mortality that are unacceptable, thus causing managers to discontinue the use of prescribed fire.

The most obvious way to avoid unwanted outcomes is to burn during weather and fuel conditions that avoid unacceptable canopy damage. Winter burning in the western US is not a common practice and no literature describes its role in either mature or young stands. This may be because it is assumed that conditions are simply too wet or under cover of snow (Knapp et al. 2005). Anthropogenic snowfall reductions in the mixed conifer region, while concerning given ecosystem service and societal impacts (Huang et al. 2018), may provide emerging opportunities for winter season prescribed fires, which in turn may help increase fuel treatment work more broadly. Winter burning is not completely new in mixed conifer forests, as Indigenous burning likely included winter burning at small spatial scales in between winter storms (Biswell 1989). A reason to be cautious with winter burns is the risk of applying silvicultural treatments that are outside of the historic disturbance regime (e.g., Seymour et al. 2002). To align strictly with the seasonality of the historic fire regime, prescribed burns would be applied in the summer or early fall (Keeley and Safford 2016). The counterargument is that studies of spring versus fall burn effects on ecological variables mainly find either small or no differences (e.g., Knapp and Keeley 2006), thus providing an ecological argument for conducting spring burns. Because vegetation is typically dormant, winter burn effects may not be distinctly negative. Independent of climate trends or ecological objectives, the logistical advantages to winter burning are significant. They include: elevated live fuel moisture allows managers to consider burning during wider ranges of wind and relative humidity; because of lower probabilities of escape, fewer personnel are needed to conduct burns; there is less need for patrolling following burns given the frequency of storms to provide mopup functions; and burn permits are much easier to obtain or may not be needed at all in some locations (York et al. 2020).

Our three study objectives are aimed at better understanding the potential for winter burning in mixed conifer forests, especially in plantations. First, we demonstrate the potential for winter burning by describing the effectiveness and conditions under which we 
conducted broadcast burns during the winter season. Second, we analyze pre- and post-burn forest structure data in order to assess which plot-level variables were the best predictors of what are most likely to be considered desirable prescribed fire effects. The purpose is to design pyrosilvicultural activities (sensu York et al. 2021) during young stand development that facilitate successful implementation of winter burns. Finally, we evaluate the frequency and duration of weather windows that have occurred during the last 20 years at the study's burn site in order to illuminate opportunities and recommend logistical strategies for winter burns.

\section{Methods}

Location and forest structural context of prescribed burns Burns were completed in mixed-species plantations at Blodgett Forest Research Station (BFRS) in the mixed conifer forest on the western slopes of the central Sierra Nevada range, which has a Mediterranean climate. From 1994 to 2020, the mean total precipitation during the wet season (further defined below) was $145 \mathrm{~cm}_{\text {year }}{ }^{-1}$. Mean daily temperature was 6.2 , mean daily low was 2.6 , and mean daily high was $10.9{ }^{\circ} \mathrm{C}$. A prescribed burn program at BFRS has been active for the past 20 years, during which burns occurred across a variety of seasons, age classes, and silvicultural systems. Recently, winter burning activity has increased. This is in part due to difficulties obtaining permits to burn during fall and spring windows across the Sierra Nevada region (York et al. 2020).

The three stands used for this study are 8 ha in size, spanning an elevation range of 1283 to $1347 \mathrm{~m}$. The stands were regenerated with clearcuts, including pileand-burn site preparation, planting, and early vegetation control with herbicide. These are common practices for this forest type when the objective is to promote rapid tree growth after a stand replacing disturbance (Stewart et al. In Press). Stands were planted with six native species: Abies concolor [Gordon \& Glend.] Lindl. Ex Hildebr., Calocedrus decurrens [Torr.] Florin, Pinus lambertiana Douglas, Pinus ponderosa Dougl. Ex Laws., Pseudotsuga menziesii (Mirb.) Franco, and Sequoiadendron giganteum (Lindl.) Buchholz. Although seedlings were planted in equal proportions among these species, survival was much higher for $P$. ponderosa and $S$. giganteum.

Two of the stands were 36 and one was 35 years old when they were burned. All three stands were masticated 5 years prior and commercially thinned with mechanized felling and whole tree yarding 3 years prior to burning. This silvicultural influence on the forest structure that occurred prior to burning is an important detail, because unthinned stands with dense canopies of this age are typically not burned at BFRS in the winter because surface fuels rarely dry out enough to carry fire. The objective of the thin was to reduce density to a target basal area of approximately $25 \mathrm{~m}^{2} \mathrm{ha}^{-1}$, while promoting increased tree species diversity and equidistant spacing among the largest available canopy trees. At the time of burning, the stands were typical of a plantation structure that would generally be seen as desirable for growth and yield of timber and carbon sequestration. Average tree size was $33 \mathrm{~cm}$ for $\mathrm{dbh}$ and $16.3 \mathrm{~m}$ for height when considering all measured trees greater than $11.4 \mathrm{~cm}$ dbh $(n=333)$. Typical of a plantation structure, tree size distribution was narrow. The standard deviation for the entire population of measured trees was $10 \mathrm{~cm}$ for $\mathrm{dbh}$ and $4.6 \mathrm{~m}$ for height. Because a study objective was to demonstrate the feasibility of winter burning, we present the weather parameters (fuel moisture, relative humidity, and temperature) under which the burns were conducted in the results. Ten-hour fuel moisture was measured immediately prior to burning with two fuel sticks in each stand. Relative humidity and temperature were measured with a weather monitor placed in each stand at approximately $1 \mathrm{~m}$ above the ground.

\section{Data collection}

Permanent 0.04 ha circular plots on a $60-\mathrm{m}$ grid were established prior to burns, resulting in ten plots per stand. This sampling intensity at the stand level was used in the national Fire and Fire Surrogate Study (Weatherspoon and McIver 2000) in stands with more within-stand variability than were used here. Within plots, all trees greater than $11.4 \mathrm{~cm}$ dbh were tagged. Trees were identified by species and measured for $\mathrm{dbh}$. Percent crown volume scorch (PCVS) for each tree was visually estimated to the nearest $5 \%$ immediately following burns. PCVS is a widely used measure of crown damage (Wooley et al. 2012). Tree status (alive or dead) was surveyed 1 year following the burns to assess post burn mortality. Pre- and post-burn shrub cover within the 0.04 ha plots was visually estimated to the nearest $5 \%$. Post-fire, the percent of each plot covered with ash was also estimated with the same method. To improve precision, shrub cover by species and ash cover was estimated within each quadrant of the plot and then averaged across the quadrants to estimate plot-level cover. Only woody shrubs were considered for analysis. The three most dominant species were Ceanothus integerrimus Hook. \& Arn., Ceanothus cordulatus Kellogg, and Arctostaphylos patula Greene.

Surface and ground fuels were sampled before and after the burns using the planar-intercept method (Brown 1974). Pre-fire measurements of fuel occurred on the morning immediately prior to ignitions, which began at 11:00. Post-fire measurements occurred 4 
months following the burns, coincident with the beginning of the wildfire season in the Sierra Nevada. Two transects per plot were established, one along contour and the second one at $+60^{\circ}$ azimuth from the first. Postfire transects were measured along the same azimuths. One-hour $(0-0.64 \mathrm{~cm})$ and $10-\mathrm{h}(0.64-2.54 \mathrm{~cm})$ fuel classes were tallied between 0 and $2 \mathrm{~m}$ along each transect. One hundred-hour $(2.54-7.62 \mathrm{~cm})$ fuels were tallied between 0 and $3 \mathrm{~m}$, and $1000-\mathrm{h}(>7.62 \mathrm{~cm})$ fuels were tallied between 0 and $11.3 \mathrm{~m}$. Duff, litter, and total fuel depths $(\mathrm{cm})$ were measured at two locations per transect. Fuel loads were calculated with species-specific coefficients developed for Sierra Nevada forests using the Rfuels package in R version 3.6.3 (van Wagtendonk et al. 1998; Foster et al. 2018). Coefficients were weighted for each transect based on the relative basal area fractions of each species derived from the specific plot's tree measurements. The two transects were averaged to obtain plot-level values. Fuel consumption was expressed proportionally, as the difference in fuel load between the post-fire and pre-fire measurements, divided by the pre-fire measurement.

BFRS has a permanent weather station that has collected continuous data at 15-min intervals since 1994. The station is centrally located within a 0.1 ha gap surrounded by a tall forest structure. We defined the winter burning season based on the combination of weather and logistical factors that realistically define burning opportunities. The winter season starts following a significant precipitation event, defined as $\geq 2.54 \mathrm{~cm}$ of precipitation in a $24-\mathrm{h}$ period. This amount of precipitation in this short amount of time typically ends what is considered to be the fall burning window (i.e., a "season ending" event). We consider the end of the winter burning period to be May 1, which is typically prior to the onset of seasonal growth by trees. Importantly, this day coincides with the typical onset of when burn permits are required, thus significantly changing the regulatory context of burning for landowners. Implicit in this timing is that conditions are generally low-risk prior to this date. Each day within this burn window was considered in prescription if relative humidity was less than $45 \%$ for at least three consecutive hours and no precipitation had fallen within the previous 10 days. This prescription is based on weather conditions that have occurred during successful winter burns in thinned mature stands conducted at BFRS over the prior decade. Wind speed was initially included in the prescription, but was never a limiting factor and so was excluded. We considered using a standard prescribed burn prescription with acceptable weather ranges and then finding days within which conditions were in prescription. However this overestimates, possibly dramatically depending on elevation, the actual number of feasible burn days. For example, low humidity and high temperatures can dry out weather station fuel sticks shortly after a snow storm, suggesting that it is a burn day when in fact there is still snow on the ground making it impossible to burn. The use of RAWS stations is also problematic for reconstructing winter burn windows, because stations are typically set up on ridge tops or open fields that are not representative of structures where understory burns would take place. Our standards for a minimum number of consecutive dry days to dry out fuels followed by at least 1 day with low humidity have proven to be consistent indicators of winter burn feasibility over the past decade of annual burning at BFRS.

Air quality conditions limit prescribed burns although practitioners did not cite it as a major barrier in the western US (Schultz et al. 2019). The California Air Resources Board (CARB) announces daily decisions on "burn" vs. "no burn" days based on atmospheric conditions. Archived CARB burn decisions from 1998 to 2020 were accessed from https://ww3.arb.ca.gov/smp/histor/ histor.htm. BFRS is located within the North Mountain Counties air basin, where allowable burn days are further categorized as either superior, good, fair, or marginal. Burning on marginal burn days is variable from district to district, but in this region burns have typically been allowed on these days. Thus, only no-burn days were considered to limit burning.

\section{Analysis}

Our first objective, which was to document the nature and effects of the burns, was met by describing the operational and environmental conditions under which the burns were conducted. Basic weather and fuel moisture data are provided. Stand-level effects $(n=3)$ are described by reporting changes in fuel load, shrub cover, ash cover, and PCVS.

The second objective of describing the structural attributes that influenced fire effects was addressed using exploratory variable selection through the least absolute shrinkage and selection operator (LASSO). LASSO is a method of obtaining interpretable, predictive models by simultaneously performing variable selection and regularization (a method to avoid fitting unrealistically complex models) (Tibshirani 1996). We applied this method for four objective-relevant metrics of prescribed fire efficacy: fine fuel consumption (excludes 1000-hour fuel), duff consumption, shrub consumption, and PCVS. For each metric, we determined a set of plot-level stand characteristics we hypothesized a priori were most likely to influence these fire effects. These were $P$. ponderosa basal area, percent canopy cover, pre-fire fine fuel load, pre-fire duff load, and pre-fire shrub cover. Stand was also considered as a factor. LASSO was used to determine which subset of these variables most 
parsimoniously predicted the observed data. We used leave-one-out cross-validation (LOOCV) to assess predictive ability at two levels: "best-fit", and "conservative" using the package gglasso in R (3.6.3) (Yang et al. 2020). LOOCV is conducted by fitting each model to an N-1 length subset of the full data and calculating the prediction error for the left out data point. This process is repeated many times for each model, and the mean prediction error is then used to assess the model's predictive ability. To make inferences from the analysis, two models and their associated explanatory variables are considered together. The best-fit model is the one which minimized out-of-sample prediction error while the conservative model is the one with the fewest predictor variables that came within one standard deviation of the minimum out-of-sample prediction error. The conservative model, as the name implies, provides an extra measure of caution against overfitting. The results of both models are reported for each metric variable (fine fuel consumption, duff consumption, shrub consumption, and PCVS).

Days that satisfied the criteria for both weather and air quality conditions were summarized by winter season and month. Average burn window length frequency was calculated over all winters and binned into categories of 1 day, 2 to 3 days, 4 to 7 days, and 8 days or longer. In order to identify if winter burn opportunities have been increasing overtime, a univariate autoregressive (AR) model was fit to the annual summary data to estimate a linear trend. Slope was estimated via maximum likelihood using an expectation-maximization algorithm, and an approximate $95 \%$ confidence interval was computed from the estimated Hessian matrix of the maximum likelihood parameter estimate. The Mann-Kendall trend test was also used to test for a monotonic trend. The AR model was fit using the MARSS package in $\mathrm{R}$ version 4.0.2 (Holmes et al. 2020; $\mathrm{R}$ Core Team 2020). The Mann-Kendall trend test was performed using the Kendall package (McLeod 2011).

\section{Results}

\section{Stand-level prescribed fire effects}

The stands were burned over a 3-day period, from February 24 through 26,2020 . Test burns confirmed the likelihood of satisfactory litter consumption. Ignitions began at approximately 11:00 and proceeded until 14:00. Ten-hour fuel moisture was 10 to $11 \%$, and relative humidity ranged from 25 to $30 \%$. Live fuel moisture, estimated by oven-drying two samples of live foliage and branches $<0.6-\mathrm{cm}$ diameter collected the day of the burns, averaged $107 \%$. Soil moisture, estimated by ovendrying three samples per stand at a depth of 0 to $5 \mathrm{~cm}$ averaged 25\%. Air temperature ranged from 15.5 to 20 ${ }^{\circ} \mathrm{C}$ and mid-flame wind speed varied from 2 to $6 \mathrm{~km}$ per hour. One stand was burned per day, each with a crew of 3 to 4 people. Strip-head firing with drip torches was used for completing burns at a pace of approximately 2 ha $\mathrm{h}^{-1}$. Flame lengths were typically less than $1.5 \mathrm{~m}$ and increased slightly each day as fuels continued to dry out. These conditions were well within the winter burning prescription that has been developed at BFRS, which is different than the prescription used for fall burning (Table 1). Generally, it is desirable for 1-h and 10-h fuel to be drier during winter burns, because of the headdampening effect that live fuel moisture and duff tend to have (Banerjee et al. 2020). Similarly, the minimum allowable relative humidity is generally lower for winter burns than fall burns due to the decreased risk of escape.

The burns spread effectively, with surface fuel consumption occurring across most areas. The percent of the ground covered with ash was $68 \%$ (std $\operatorname{dev}=23 \%$ ), $80 \%$ (std dev $=6 \%$ ), and $90 \%$ (std dev $=20 \%$ ) for each of the three stands. Some of the unburned forest floor was caused by skid trails, where there was a lack of fuel. Each successive day of burning led to an increased amount of the forest floor being covered with fire, presumably following a climatic drying trend that was creating more receptive fuel conditions across the burning window. At the stand level, the prescribed fires consumed a substantial amount of fine fuels (59\% on average) and, as expected, much lower amounts of large fuels and duff (Table 2). Shrub cover was reduced dramatically, by $94 \%$ on average. We observed torching of shrubs to be very common, but did not observe any torching of mid-story or canopy trees. One year after the fires, some shrubs had re-sprouted to bring average cover to $5 \%$, which was still lower than the pre-fire cover of $21 \%$.

Canopy tree damage and mortality 1 year after the fires was generally low. No canopy trees $(n=223)$ that were in the permanent plots died during the first year following the fires. For mid-story trees, mortality was 0 $3 \%$. This mid-story mortality may have been caused by the fires, although field crews could not attribute mortality to the fires with certainty. Crown damage (PCVS) of

Table 1 Environmental prescription ranges for winter burning and fall burning at BFRS

\begin{tabular}{llllll}
\hline & \multicolumn{2}{l}{ Winter } & & \multicolumn{2}{l}{ Fall } \\
Parameter & Low & High & & Low & High \\
\hline Relative humidity (\%) & 45 & 18 & & 65 & 23 \\
6.1 m height wind speed $\left(\mathrm{km} \mathrm{h}^{-1}\right)$ & 8 & 24 & 8 & 16 \\
Mid-flame wind speed $\left(\mathrm{km} \mathrm{h}^{-1}\right)$ & 2.4 & 9.7 & & 2.4 & 4.8 \\
Temperature $\left({ }^{\circ} \mathrm{C}\right)$ & 3 & 27 & 3 & 27 \\
1-h fuel moisture $(\%)$ & 13 & 3 & & 13 & 5 \\
10-h fuel moisture (\%) & 12 & 5 & & 14 & 5.5 \\
\hline
\end{tabular}


Table 2 Change in fuel loads and shrub cover following winter burns in mixed conifer plantations. The means are based on three stands, each with 10 sample plots on a 60-m grid and two fuel transects per plot. Variability in consumption between stands can be seen from the \% reduction columns

\begin{tabular}{|c|c|c|c|c|c|}
\hline & Pre burn mean ( $n=3$ stands) & Post burn mean ( $n=3$ stands) & $\%$ reduction burn 1 & $\%$ reduction burn 2 & $\%$ reduction burn 3 \\
\hline Fine fuels & $31.9 \mathrm{mg} \mathrm{ha}^{-1}$ & $13.1 \mathrm{mg} \mathrm{ha}^{-1}$ & 58 & 42 & 78 \\
\hline $1000 \mathrm{~h}$ & $1.1 \mathrm{mg} \mathrm{ha}^{-1}$ & $0.8 \mathrm{mg} \mathrm{ha}^{-1}$ & 48 & 24 & 7 \\
\hline Duff & $28.6 \mathrm{mg} \mathrm{ha}^{-1}$ & $24.5 \mathrm{mg} \mathrm{ha}^{-1}$ & 11 & 2 & 31 \\
\hline Shrub cover & $21 \%$ & $1 \%$ & 86 & 96 & 98 \\
\hline
\end{tabular}

canopy trees averaged $25.5 \%$ and varied among the three stands, from 10 , to 27 , to $40 \%$, increasing on each successive day of burning.

\section{Statistically modeled prescribed fire effects}

The best-fit model for explaining fine fuel consumption at the plot level included the variables $P$. ponderosa basal area, percent canopy cover, pre-fire fine fuel load, prefire duff load, and stand. It did not include pre-fire shrub cover. The greatest amount of fuel consumption occurred on the third day of burning, and also where pre-fire fuel load was higher. Most of the leverage in the relationship between pre-fire fuel load and fuel consumption came from a few plots with low fuel loads that had either zero or negative fuel consumption (Fig. 1A). Canopy cover, which we believed could be a strong predictor of fuel consumption based on Levine et al. (2020), was at best weakly correlated despite our plots having a wide range of canopy cover values (Fig. 1B). The conservative model did not support any of our variables as
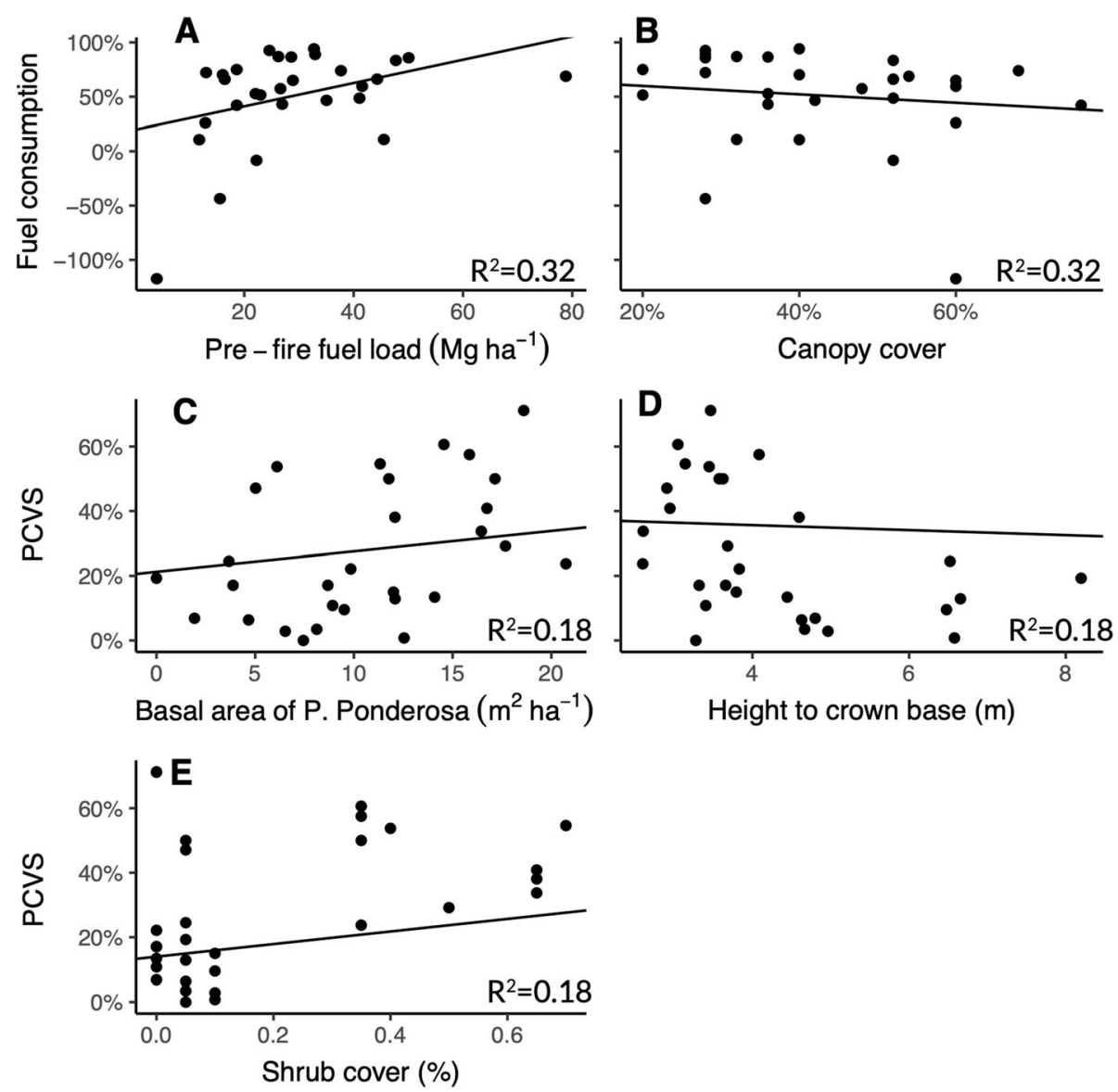

Fig. 1 Points in panels A-E show the observed relationships between A pre-fire fuel load and fuel consumption, B canopy cover and fuel consumption, $\mathbf{C}$ P. ponderosa basal area and PCVS (percent crown volume scorch), $\mathbf{D}$ height to crown base and PCVS, and $\mathbf{E}$ shrub cover and PCVS. Not all variables included in the best-fit models are shown here, only ones with significant ecological relevance. Solid lines indicate the predicted values from the best-fit models for each response variable. $R^{2}$ values for the corresponding best-fit models are given in each panel 
strong predictors of fuel consumption, but it did verify that meaningful fuel consumption (i.e., fuel reductions of $50 \%$ or more) occurred at the plot level.

Change in duff at the plot level was not explained well with any of our variables. It was not the case that higher duff loads impeded fine fuel consumption, but duff consumption was generally low (2-31\% at the plot level), as expected. Variability associated with duff load and consumption make it especially difficult to find predictors at the plot level (e.g., Westfall and Woodall 2007). The best-fit model for explaining change in shrub cover included pre-fire fuel load as a predictor, but the change in shrub cover with fuel load was minimal $(<1 \%$ additional increase in fuel consumed per additional $\mathrm{Mg} \mathrm{ha}^{-1}$ of load). The conservative model did not reveal any relationships between shrub cover changes and our measured variables. Overall, this reflects the fact that shrub cover was reduced dramatically whenever it was present on most plots regardless of the specific structure surrounding the shrubs.

PCVS was the response variable where the most nuance in the predictor variables could be seen, albeit only when using the best-fit procedure. This suggested a positive relationship between PCVS and both $P$. ponderosa basal area and pre-fire shrub cover and a negative relationship with height to crown base. Particularly high levels of PCVS $(>50 \%)$ tended to occur in plots with more than $5 \mathrm{~m}^{2} \mathrm{ha}^{-1}$ of $P$. ponderosa basal area (Fig. 1C) or when there was less than $5 \mathrm{~m}$ of average height to crown base (Fig. 1D). Moderate levels of PCVS (>25\%) occurred when shrub cover was greater than $30 \%$ (Fig. 1E). As with the other variables, the conservative model tended to support that PCVS was significant in magnitude (compared to zero change), but that there were no particularly strong predictors among those that we considered.

\section{Weather windows for winter burning over the past 20 years}

Of the 4851 days that occurred during the winter periods from 1994 to 2020,320 of them were feasible burn days where both adequate weather and air quality conditions coincided. Annual variability was considerable (Fig. 2), ranging from zero days (this occurred in 19951996 and again in 2016-2017) to 33 days in 2013-2014, which was within an exceptional multi-year drought that occurred across the region. On average, 12 days per winter were feasible for burning using our criteria. Of the total days that were in prescription in terms of weather conditions, 33\% were designated by CARB as no-burn days. There was insufficient evidence of a linear or a monotonic trend for the number of days in prescription per winter. The approximate $95 \%$ confidence interval for the slope estimate from the AR model overlapped with zero, and the Mann-Kendall trend test was not statistically significant ( $\tau=0.090,2$-sided $P=0.536$ ).

The month in which burning windows occurred also varied greatly from year to year (Fig. 3). October and January had the highest average number of days in prescription from 1994 to 2020 (2.9 and 3.1 days per winter, respectively). October had much more variation over time than January, with many years having no days in prescription during this month because the precipitation-initiating winter period sometimes did not start until at least late October. November had the lowest average number of days in prescription per winter (0.6 days).

CARB no-burn decisions, which reduced feasible burn days by $33 \%$, did not limit all months uniformly. While days in prescription in terms of weather conditions were less common in February, March, and April, fewer of these $(23 \%)$ were designated as no-burn days. This percentage was higher in the first half of winter, from October to January, where $53 \%$ of days in prescription were no-burn days.

The majority of windows when conditions were suitable for burning from 1994 to 2020 were 1 to 3 days long (Fig. 4). One-day burn windows were most frequent, occurring 1.5 times per winter on average. Occurrence of either 2 or 3-day burn windows occurred about 1.6 times per winter on average. Windows lasting longer than 3 days were relatively rare, occurring on average 1.1 times per winter. During days when burn opportunities occurred, the weather conditions came into prescription most often at 11:00 and ended by 16:00.

\section{Discussion}

Pyrosilviculture treatments to facilitate winter burns

The use of prescribed fire in young stands is considered experimental because studies are sparse relative to mature forests (North et al. 2019). Yet there is enough recent work to characterize variability in mortality and damage levels (Table 3). A common experimental treatment prior to conducting burns has been mastication, an activity that was cautioned against by Kobziar et al. (2009) when trying to lower wildfire severity in the short term. However, in mature forests mastication treatments have performed well in terms of lowering fire severity once masticated fuel decomposes (Stephens et al. 2012). When viewed as a pyrosilviculture treatment-that is, one that increases opportunities for using prescribed fire-then mastication has some possible advantages that are distinct to a winter burning approach. Mastication primarily acts to remove the mid-story component of forest structure, redistributing it in small pieces to the forest floor. Removal of the mid-story influences several fire behavior properties connected to air flow such that fires are predicted to be hotter when occurring during 


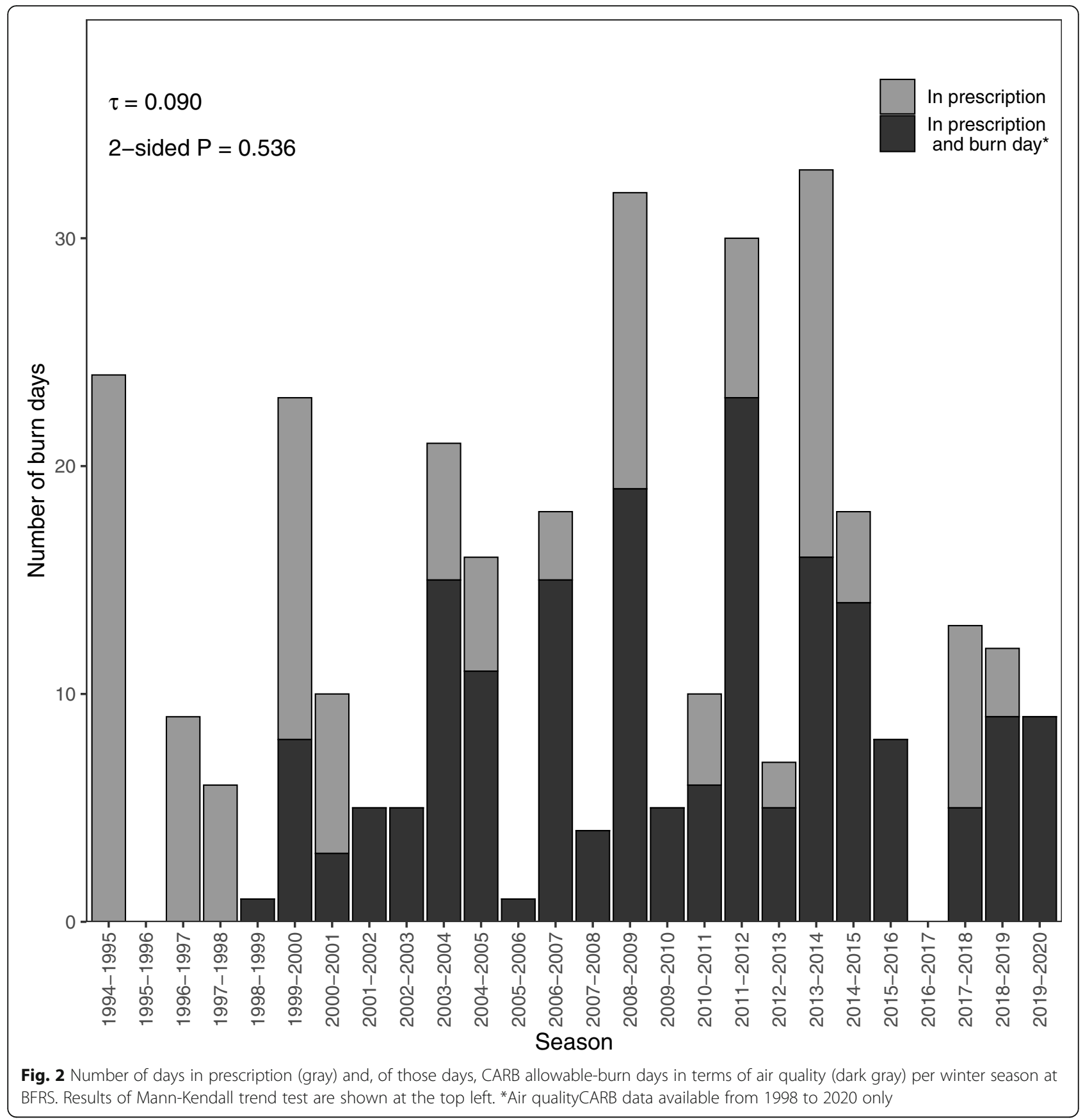

more moist fuel conditions (Banerjee et al. 2020). The stands for this study were masticated 5 years prior to the burns and were also commercially thinned 3 years prior, creating relatively open mid-story conditions when they were burned. As noted in the "Methods" section, the experience of burning at BFRS over the last two decades suggests that winter burning is more feasible in stands where the structure has been manipulated in order to increase the rate at which surface fuels dry out during winter dry periods. Thus, the "success" of winter burning described here may not consistently translate to dense stands that were not manipulated prior to burning. While pre-treatments may increase the potential to conduct winter burns, they are not necessarily a prerequisite. During the less common multi-day windows, even dense canopy stands may be burnable during the winter period. Of the last 10 winter burns that BFRS has done, only two of them were in stands where the canopy had not been thinned within the past 10 years. Future studies in the mixed conifer and other forest types that explore different options of structural manipulation and prescribed fire timing (e.g., mid-story removal and time 


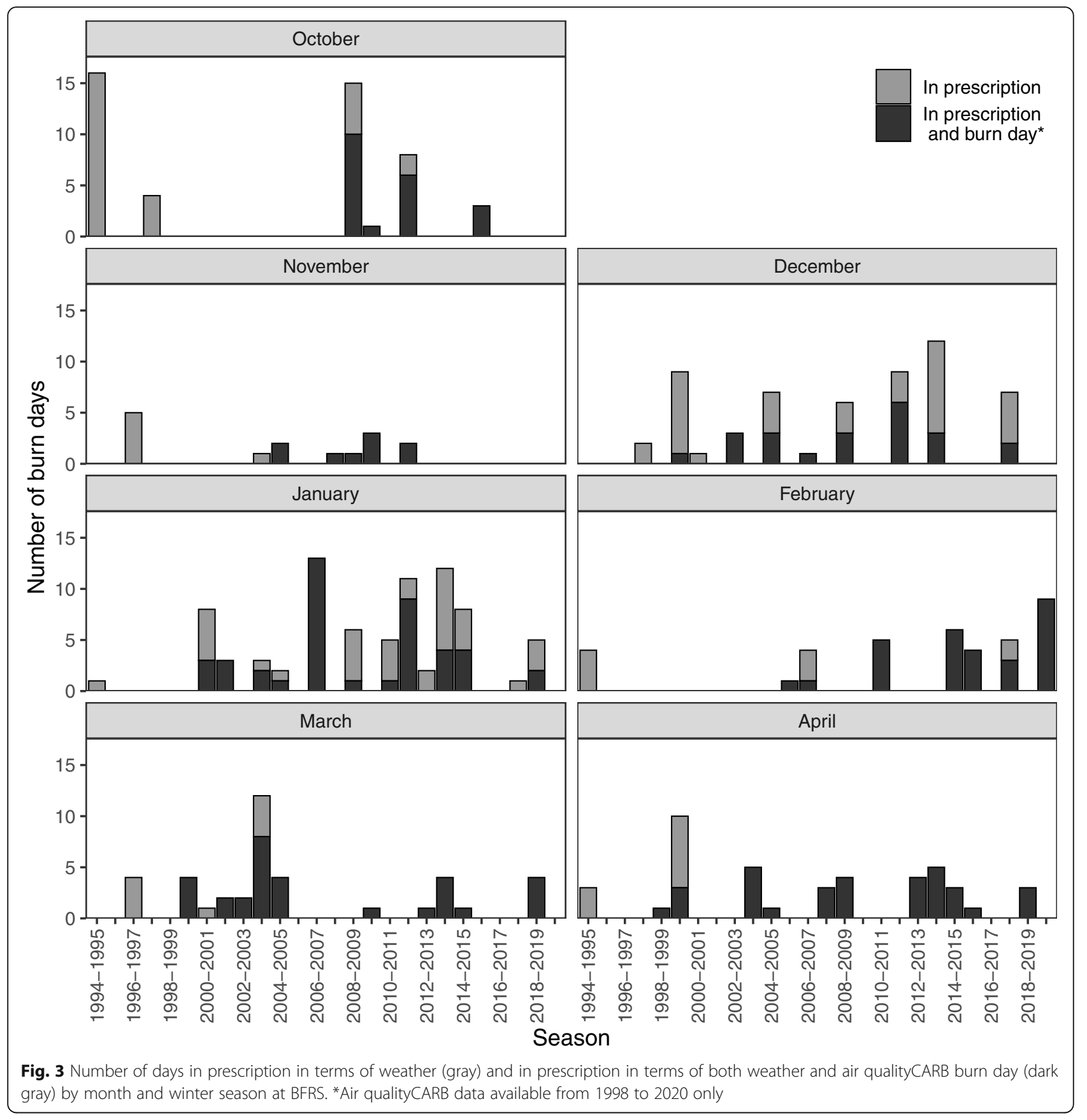

since mastication) could contribute to understanding effective pyrosilviculture approaches in plantations.

With mastication, the removal of the mid-story translates directly to an increase in fine fuels that can increase fireline intensity during dry fuel conditions (Stephens and Moghaddas 2005b). Unlike fall burns, where the weather and fuel conditions enter the prescription from the high (i.e., hot/dry) end of the range and practitioners are waiting for predicted effects to be less severe (Table 1), winter burns enter the prescription from the low (i.e., cool/moist) end of the range. This means that practitioners are waiting for conditions to improve such that the minimal level of effective fuel consumption becomes possible. This suggests that structures that increase expected fire intensity may be beneficial for winter burning because prescription windows open up earlier and provide more opportunities to burn. Hence while burning recently masticated $(<1$ year) material in the fall may be risky in terms of canopy damage (Kobziar et al. 2009; Stephens and Moghaddas 2005b), it may provide amenable conditions in the winter. And if a combined mastication plus burn is prescribed in order to 


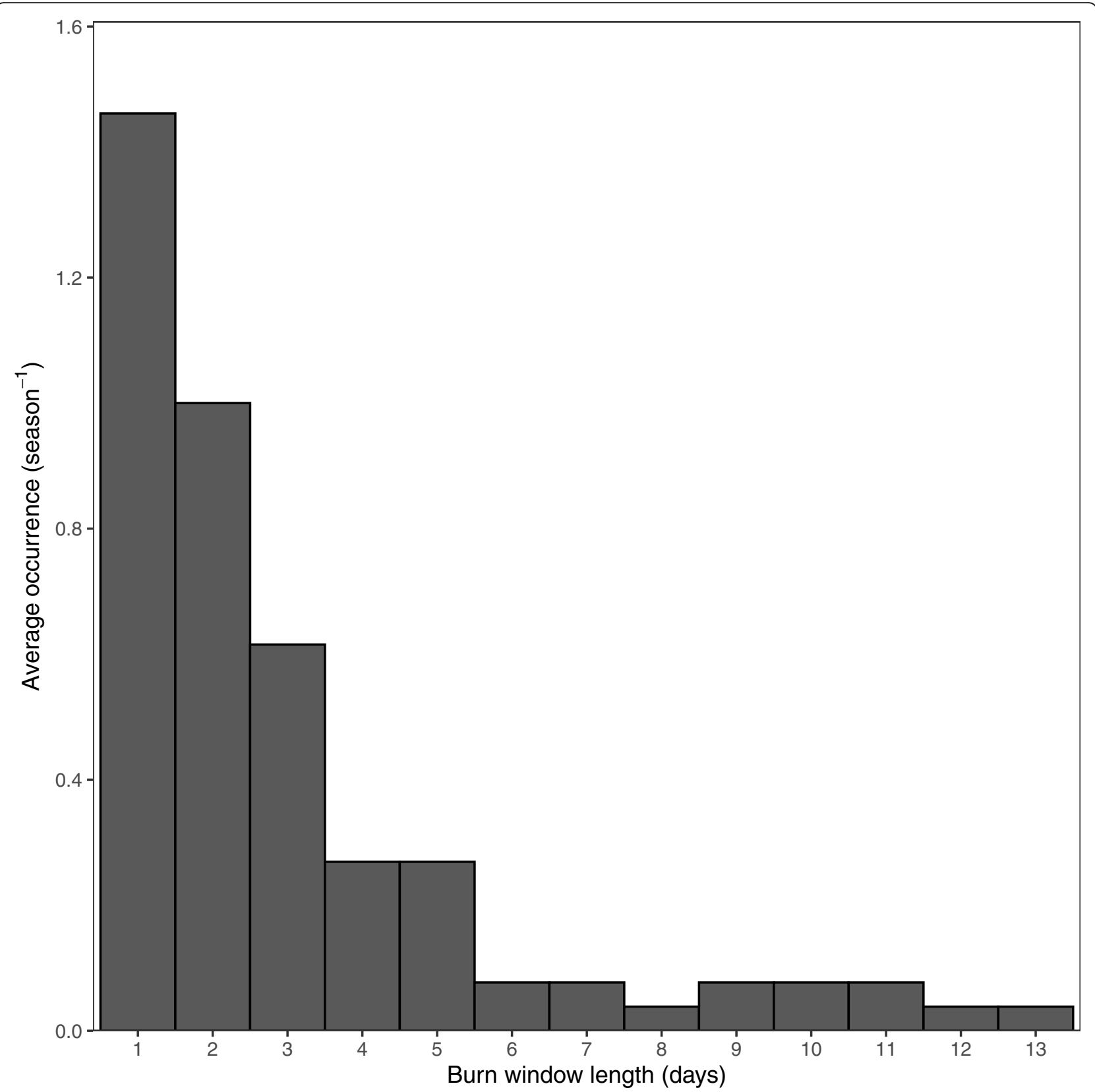

Fig. 4 Average occurrence of burn window lengths per winter season at BFRS, 1994-2020.

reduce both mid-story and surface fuels as quickly as possible, then waiting to burn the masticated fuel in the winter period, rather than in the fall, could be a way to avoid canopy damage while consuming the masticated fuel prior to the incoming summer wildfire season. Mastication clearly has not always led to hot burns during the fall, as Table 3 demonstrates that it has been a prelude to both high (e.g., York et al. 2021) and low levels of mortality (e.g., Bellows et al. 2016). While our study reports relatively low levels of damage and nearly nonexistent mortality, burning in the winter can still cause high canopy damage when conditions are dry (Reiner et al. 2012).

Another potential pyrosilvicultural treatment in plantations is thinning that removes whole trees. As with mastication, whole tree thinning is likely to influence fire behavior such that intensity increases compared to unthinned stands during winter burns (Banerjee et al. 2020) thus increasing surface fuels consumption when burning. The burns that followed commercial thins (this study, Busse and Gerrard 2020, York et al. 2021) all had relatively low levels of 
Table 3 Tree mortality and crown damage reported from plantation burns in the western US. CT commercial thin, PCT precommercial thin, PCVS percent crown volume scorch

\begin{tabular}{|c|c|c|c|c|c|c|}
\hline Spp composition & $\begin{array}{l}\text { Stand age } \\
\text { (years) }\end{array}$ & $\begin{array}{l}\text { Season of } \\
\text { burn }\end{array}$ & $\begin{array}{l}\text { Pre burn } \\
\text { treatments }\end{array}$ & $\begin{array}{l}\text { Years until mortality } \\
\text { survey }\end{array}$ & $\begin{array}{l}\text { Percent } \\
\text { mortality }\end{array}$ & $\begin{array}{l}\text { PCVS } \\
\text { (\%) }\end{array}$ \\
\hline Mixed-conifer ${ }^{1}$ & $35 / 36$ & Winter & $C T$ & 1 & 3 & 25 \\
\hline Mixed-conifer $^{2}$ & $12 / 13$ & Fall & Mastication & 1 & 6 & 17 \\
\hline Mixed-conifer ${ }^{3}$ & 32 & Fall & $C T$ & $<1$ & 6 & 59 \\
\hline P. ponderosa ${ }^{4}$ & $44 / 55 / 62$ & Spring (2 burns) & $C T$ & 17 & 6 & -- \\
\hline P. ponderosa $a^{5}$ & 40 & Spring & Mastication & 3 & 7 & 46 \\
\hline Mixed-conifer ${ }^{2}$ & $12 / 13$ & Fall & None & 1 & 9 & 22 \\
\hline P. ponderosa ${ }^{6}$ & 25 & Winter & Mastication + raked & 1 & 17 & 75 \\
\hline P. ponderosa ${ }^{7}$ & 52 & Summer & None & 4 & 24 & -- \\
\hline P. ponderosa ${ }^{4}$ & $45 / 55 / 62$ & Spring (2 burns) & None & 17 & 24 & -- \\
\hline P. ponderosa ${ }^{6}$ & 25 & Winter & Mastication & 1 & 32 & 74 \\
\hline $\begin{array}{l}\text { P. ponderosa /P. } \\
\text { menziesii }^{7}\end{array}$ & $25-34$ & Spring & None & $<1$ & 34 & -- \\
\hline P. ponderosa ${ }^{5}$ & 40 & Spring & Mastication & 3 & 35 & 58 \\
\hline Mixed-conifer ${ }^{3}$ & 22 & Fall & None & $<1$ & 38 & 62 \\
\hline Mixed-conifer ${ }^{3}$ & 12 & Fall & $\mathrm{PCT}$ & $<1$ & 48 & 52 \\
\hline Mixed-conifer ${ }^{3}$ & 12 & Fall & Mastication & $<1$ & 48 & 78 \\
\hline Mixed-conifer ${ }^{2}$ & $12 / 13$ & Spring & Mastication & 1 & 49 & 63 \\
\hline
\end{tabular}

${ }^{1}$ This study, ${ }^{2}$ Bellows et al. (2016), ${ }^{3}$ York et al. (2021), ${ }^{4}$ Busse and Gerrard (2020), ${ }^{5}$ Knapp et al. (2011), ${ }^{6}$ Reiner et al. (2012), ${ }^{7}$ Zhang et al. (2020)

post-burn mortality. One explanation for this is that thinning removed smaller trees that were more vulnerable to fire-related mortality, leaving behind vigorous trees with thicker bark and higher crown bases. In this study, whole trees were removed and processed for sawlogs, but other options such as removing whole trees for biomass energy production or yarding and then burning at landings would have a similar effect on stand structure. While further studies may help reveal patterns, our expectation following this and other studies to date is that thinning combined with whole tree yarding and followed by winter burning may be an especially effective approach for managing surface fuels in plantations while avoiding high levels of damage and mortality. Importantly, revenue from commercial thinning can cover the operational costs of prescribed fires, especially low-cost winter burns, depending on market conditions and product type (Hartsough et al. 2008).

\section{Plot-level forest structural factors of prescribed fire effects}

Plot-level analyses of the factors of fuel consumption did not find clear correlations with plantation structural attributes. Although the plots in this study were somewhat variable in their structure (Fig. 1), this represents only a small range of conditions that can occur in mixed conifer plantations. Stand age, site productivity, species composition, and treatment history range widely in the western US. Future work could widen the range of experimental structural conditions more broadly. For example, burning plantations with different levels of midstory removal (Banerjee et al. 2020) or testing different lengths of time between masticating and burning, could help to better understand how to prepare plantations for burning. It is also worth noting that there could be seasonal trends in consumption within the winter period that were not captured in this study. For example, 1000h fuels may have been consumed more thoroughly had these burns occurred in November rather than February, when cumulative precipitation saturates larger fuels. While our plots sizes ( 0.04 ha) were typical of many fire effects studies, some correlations may have been clearer with larger plot sizes, although this may not be the case in plantations such as these, where structural variability is fairly low.

If generally low consumption of duff is typical of winter burns, as was the case here, it may be difficult to characterize duff consumption as a factor of certain structural characteristics. Instead, the implication with respect to duff consumption during winter burns is simply that not very much of it occurs. As noted by our soil moisture measurements, winter burns occur during moist soil conditions, likely contributing to the general lack of duff combustion. Unlike generally drier fall burns in mature forests (Levine et al. 2020), these winter burns were modest at best in consuming duff. When compared to burning prior to precipitation in the fall, burning after 
even a small amount of precipitation can lead to considerable variation in amounts of duff consumption (Hille and Stephens 2005). Compared to litter and fine fuels, duff fuels do not appear to become receptive to consumption during these winter burning windows. While duff was recalcitrant in this regard, we also did not find them to be obstacles to consumption of fine fuels. An important context of duff consumption in plantations is that duff load is typically not very high to begin with due to earlier site preparation practices and the lack of time for it to develop. Instead of actively decreasing duff loads, therefore, winter burns may function more to limit its future development by maintaining low litter loads which are the supply of future duff loads.

Crown damage was generally low across plots, although some did experience amounts of scorch (i.e., $>50 \%)$ that may be considered undesirable. While plots with more $P$. ponderosa had more crown scorch, this species has also been observed to be capable of surviving extensive scorch well compared to other species (Harrington 1993). Given that scorch damage occurs low on the crown, where branches are less productive in terms of contributing to growth (Sprugel et al. 1991), it may be that these levels of scorch do not negatively influence long-term growth. Further, scorch of lower branches increases height to crown base of canopy trees, a generally positive effect with respect to reducing crown fire potential. If crown scorch is undesirable for other reasons such as esthetic quality, then managing for fewer $P$. ponderosa would seem to be a logical implication. This, however, would likely be trading scorch for mortality since $P$. ponderosa in young stands are relatively good survivors of scorch (York et al. 2021). Lowering shrub cover in locations with particularly high amounts of shrubs could be a reasonable way to reduce crown scorch. Our results, however, suggest that only the lowest of management tolerance for crown scorch may justify reducing shrubs prior to burning.

The dramatic reduction of shrub cover achieved in this study may be of particular interest to managers. We demonstrated that winter burns can be a cost-effective way to reduce shrub cover as opposed to using costly mechanical or undesired chemical treatments before applying fire. The dominant shrub species at this site (Ceanothus integerrimus, Ceanothus cordulatus, and Arctostaphylos patula) are well-known to be competitive with young trees in this forest type, and all three are common targets during release treatments. While torching of shrubs can occur given their close proximity to surface fire intensity, high moisture contents can limit torching (Van Wagner 1977), causing them to be "heat sinks" during prescribed burns, where they inhibit fire spread rather than facilitate it. The result of significant shrub reductions from this study suggests that dry periods in the winter can provide adequately low live fuel moisture conditions for reducing shrub cover with prescribed fire. Monitoring the rate of post-fire shrub recovery and describing shrub dynamics over time before and after follow-up burns will be a relevant topic to explore in the future.

\section{Winter burn windows occur but are sporadic and fleeting} Unlike in southeastern US forests, where winter burning is common in part because of the predictability of burn windows (Hiers et al. 2000), the occurrence of winter burn windows in the western US is less predictable. Periods during the winter at this location when both weather and air quality conditions allow for feasible burns do not occur during long windows. Rather, they occur during "winks" of time that can occur in any month on any given year. Developing weather prescription ranges during the winter period is complicated by the fact that by the time fuel realistically dries out enough to conduct a burn, a winter storm will soon reset fuel into saturated conditions. While consideration for local weather and fuel conditions is always a dominant factor in deciding when to burn (Biswell 1989), it may be even more important for winter burns. At higher elevations or latitudes than our site, more drying time would be needed given higher amounts of snowfall per storm. At raindominated lower elevations or latitudes, less time would be needed. In our experience at this site, a minimum of 10 days of drying time is needed following winter storms. This varies considerably depending on the details of the fuel structure (e.g., $P$. ponderosa needles versus $A$. concolor leaves) and topography (e.g., south versus west facing slopes), but it has been a dependable rule of thumb.

The fleeting nature of winter burn windows requires a specifically designed approach to preparations for burning. Most importantly, it requires being nimble. If multiple days of in-prescription conditions are needed to justify burning, then the opportunity has likely already passed. For large agencies focused on increasing temporary staffing during summer wildfire seasons, this is a challenge. However, large landowners and agencies have the advantage of being able to hedge bets operationally across a wide range of conditions that occur in the winter. For example, preparing pile burn projects at higher elevations can keep personnel active until lower elevation sites become available for broadcast burning. Regardless of the exact approach, winter burning means having personnel hired and available throughout the winter period. For private landowners with smaller ownership sizes, winter burning may come easier than for large programs, or it may be the only feasible option to burn at all. In California, permitting during the fall period can restrict burning, even when conditions are 
ideal (York et al. 2020). The removal or lessening of the permitting constraint during the winter period is thus a significant advantage. Importantly, our burns demonstrate a lower complexity of winter burns, as each 8 ha stand was burned with a four person crew.

Striplin et al. (2020) also considered burn window opportunities in the Sierra Nevada and documented that winter burn windows existed in conifer forests that were drier but also colder and with precipitation much more dominated by snow compared to our site. Whereas Striplin et al. (2020) found approximately half of winter days to be in prescription in terms of fuel and weather conditions, we found it to be much lower (7\%). There are several reasons for this difference. First, our study used a weather station that was located near the burn locations and thus avoided low humidity readings that can come from exposure to dry winds on ridge tops. Second, unlike in Striplin et al. (2020) which did not apply any minimum drying out time, this study applied a minimum period of 10 days following the last precipitation. Finally, this study applied a prescription that was specific to winter burns and was not a general prescription applied all year. Whereas Striplin et al. (2020) labeled a burn day as one where any hour during the day had humidity less than $50 \%$ and 10 -h moisture less than $20 \%$, we required burn days to have at least $3 \mathrm{~h}$ at less than $45 \%$ relative humidity in order to be realistic in terms of burn operation efficiency. We did not include dropping below a maximum 10-h fuel moisture, which has been observed to be underestimated when using RAWS stations (Estes et al. 2012). The winter burning prescription developed using experience at BFRS requires 10-h fuels to be less than $12 \%$, considerably lower than the $20 \%$ maximum used at the higher elevation site. We point out these differences to underscore the importance of deriving specific winter burn prescriptions at local levels.

Burns at BFRS have been allowed on all fair and most marginal burn days. Additionally, exceptions have been given to conduct small winter burns on no-burn days when a justification is provided. This experience explains our different methodology in labeling days as burn versus no-burn days compared to Striplin et al. (2020), who did not include any marginal or even fair burn days as acceptable air quality burn days. Despite our inclusive approach to labeling days as acceptable in terms of air quality, the number of days on which air quality restricted burning was surprisingly high. Although it is often listed as a constraint (e.g., Quinn-Davidson and Varner 2012), air quality has recently been described by practitioners across the western US as not being a major impediment except in some locales (Schultz et al. 2019). Our analysis suggests that air quality is a significant constraint in this region during the winter period. That air quality was more of a constraint toward the end of the winter period as it transitions to the spring season does not conform to the expectation that the fall/early winter season has atmospheric conditions that are less conducive to burning (Cahill et al. 1996). The net effect was a smoothing-out on the frequency of burning opportunities across the winter period (Fig. 3).

\section{Conclusions and management implications}

The potential logistic, economic, and risk-avoidance advantages of winter burning should be appealing for managers who want to both insulate economic investments and also protect future ecosystem services gains that can come from developing mixed species plantations. Until results from winter burning trials are evaluated, however, it remains a concept with appeal but lacking in proof. Here, we contribute evidence that winter burning can be feasible and effective for common prescribed burn objectives, albeit with limitations.

As with numerous other forest types throughout the western US, there is an urgency to increase the use of prescribed fire in mixed conifer forests. Yet actual implementation of broadcast burning lags far behind desired goals. In the 2016-2017 fiscal year, the most recent period for which information is available, state agency burning occurred on less than 5700 hectares across the state (Brown et al. 2018). This could be a vast overestimate of broadcast burning on forestlands, since it includes both pile burning and grassland burning. Winter burning, especially in young stands managed with pyrosilvicultural treatments prior to burning, may be an overlooked opportunity to lower wildfire severity in structures that are otherwise particularly vulnerable. In the context of young stands managed for timber with even-aged management, prescribed fires could be used multiple times in the lifespan of a managed stand. At our study site, long-term tracking of mean annual volume increments suggest that approximately 100 years is an optimal rotation age in terms of maximizing yield (BFRS, unpublished data). In fully stocked plantations with increasing leaf areas, fuel loads will recover quickly following prescribed burns, suggesting frequent prescribed burning in order to maintain low fuel loads (York et al. 2021). Each subsequent burn ostensibly will have less canopy damage, as trees get larger and lower portions of crowns that are scorched are no longer present. One approach to burn timing may be to conduct burns following commercial thins, thus taking advantage of lower canopy densities to dry fuel and also to consume activity fuel associated with harvesting. This would likely translate to three or four burns prior to rotation age, depending on the type of thinning regime that is applied.

On forestlands not managed with a timber objective, avoiding or staying below certain levels of mortality may 
not be as relevant. Instead, significant fire damage and tree mortality may be desirable if it is relied upon as the primary density management tool. However, even with a more broad range of acceptable outcomes following prescribed fires, federal mixed conifer lands also lag far behind compared to desired use of fire (North et al. 2012). Given low levels of duff and large-diameter fuel consumption as was found here, winter burning on federal lands may function more appropriately as maintenance burns that follow wildland fire use or hot initial-entry prescribed burns that have more thorough consumption and canopy tree mortality. Instead of mechanical treatments creating the conditions that are amenable for successful winter burns, as occurred in this study, hot fires could also facilitate structures where winter burns could more feasibly be applied as maintenance treatments. For landowners with a low tolerance for canopy tree damage, winter burning could be strategically planned as a firstentry burn that reduced more hazardous fuels (i.e., fine fuels) without causing excess damage. Subsequent fall burns during dry conditions could then be carried out with a lower risk of damage. For a variety of landowner types and corresponding objectives, the winter period may represent an overlooked opportunity to advance overall burn program objectives.

\section{Acknowledgements}

We acknowledge A. Roughton and H. Noble for assistance with burning. B. Collins provided a helpful review of the manuscript.

\section{Authors' contributions}

RY was the burn boss, supervised the data collection, conceptualized the study, conducted the analysis, and wrote the manuscript. JL conducted the analysis and edited the manuscript. KR collected the data, conducted the analysis, and edited the manuscript. JR helped conceptualize the study and edited the manuscript. The authors read and approved the final manuscript.

\section{Funding}

The authors acknowledge funding support from the SPARx-Cal (Smart Practices and Architectures for Rx fires) project under the University of California Laboratory Fees Research Program funded by the UC Office of the President (UCOP), grant ID LFR-20-653572, entitled "Transforming Prescribed Fire Practices for California."

\section{Availability of data and materials}

The datasets used and/or analyzed during the current study are available from the corresponding author on reasonable request.

\section{Declarations}

Ethics approval and consent to participate

This study did not involve the use of any animal or human data or tissue.

\section{Consent for publication}

This study did not contain data from any individual person.

\section{Competing interests}

The authors declare that they have no competing interests.

\section{Author details}

'Department of Environmental Science, Policy, and Management, UC Berkeley, Berkeley, USA. ²Department of Ecology and Evolutionary Biology, Princeton University, Princeton, USA. ${ }^{3}$ California Department of Forestry and
Fire Protection, Forest and Fire Resource Assessment Program, Sacramento, USA.

Received: 14 April 2021 Accepted: 10 September 2021

Published online: 06 November 2021

\section{References}

Agee, J.K. 1993. Fire ecology of Pacific Northwest forests, 493. Covelo: Island Press. Baldwin, H., W. Stewart, and S. Sommarstrom. In Press. Reforesting California. In Reforestation Practices for Conifers in California, ed. W. Stewart. Davis: University of California Agriculture and Natural Resources https://www.fvmc. org/.

Banerjee, T., W. Heilman, S. Goodrick, J.K. Heirs, and R. Linn. 2020. Effects of canopy midstory management and fuel moisture on wildfire behavior. Nature Scientific Reports 10 (1): 17312. https://doi.org/10.1038/s41598-02074338-9.

Bellows, R.S., A.C. Thomson, K.J. Helmstedt, R.A. York, and M.D. Potts. 2016. Damage and mortality patterns in young mixed conifer plantations following prescribed fires in the Sierra Nevada, California. Forest Ecology and Management 376: 193-204. https://doi.org/10.1016/j.foreco.2016.05.049.

Biswell, H.H. 1989. Prescribed burning in California wildlands vegetation management, 44. Berkeley: University of California Press.

Brown, EG, J Laird, and K Pimlott. 2018. California's forest and rangelands: 2017 assessment. Ogten: http://frap.fire.ca.gov/assessment2017.

Brown, J.K. 1974. Handbook for inventorying downed woody material. USDA Forest Service, General Technical Report INT-16.

Busse, M., and R. Gerrard. 2020. Thinning and burning effects on long-term litter accumulation and function in young ponderosa pine forests. Forest Science 66 (6): 761-769. https://doi.org/10.1093/forsci/fxaa018.

Cahill, T.A., J.J. Carroll, D. Campbell, and T.E. Gill. 1996. Air quality. In Sierra Nevada Ecosystem Project, Final Report to Congress, vol. II, Assessments and Scientific Basis for Management Options, 1227-1260. Davis: University of California Davis, Centers for Water and Wildland Resources.

Estes, B.L., E.E. Knapp, C.N. Skinner, and F.C.C. Uzoh. 2012. Seasonal variation in surface fuel moisture between unthinned and thinned mixed conifer forest, northern California, USA. International Journal of Wildland Fire 21 (4): 428-435. https://doi.org/10.1071/WF11056.

Foster, D., S. Stephens, J. Moghaddas, and J. Van Wagtendonk. 2018. Rfuels: forest fuels from Brown's transects. Berkeley: URL https://github.com/danfosterfire/ Rfuels. Accessed 5 Feb 2021.

Han, S.-K., H.-S. Han, D.S. Page-Dumroese, and L.R. Johnson. 2009. Soil compaction associated with cut-to-length and whole-tree harvesting of a coniferous forest. Canadian Journal of Forest Research 39 (5): 976-989. https:// doi.org/10.1139/X09-027.

Harrington, M.G. 1993. Predicting Pinus ponderosa mortality from dormant season and growing season fire injury. International Journal of Wildland Fire 3 (2): 65 72. https://doi.org/10.1071/WF9930065.

Hartsough, B.R., S. Abrams, R.J. Barbour, E.S. Drews, J.D. Mclver, J.J. Moghaddas, and S.L. Stephens. 2008. The economics of alternative fuel reduction treatments in western United States dry forests: Financial and policy implications from the National Fire and Fire Surrogate Study. Forest Policy and Economics 10 (6): 344-354. https://doi.org/10.1016/j.forpol.2008.02.001.

Hiers, J.K., R. Wyatt, and R.J. Mitchell. 2000. The effects of fire regime on legume reproduction in longleaf pine savannas: is a season selective? Oecologia 125 (4): 521-530. https://doi.org/10.1007/s004420000469.

Hille, M.G., and S.L. Stephens. 2005. Mixed conifer forest duff consumption during prescribed fires: Tree crown impacts. Forest Science 51 (5): 417-424.

Holmes, E, E Ward, M Scheuerell, and K Willis. 2020. MARSS: Multivariate autoregressive state-space modeling. R package version 3.11.3. https://cran.rproject.org/web/packages/MARSS/MARSS.pdf.

Huang, X., A.D. Hall, and N. Berg. 2018. Anthropogenic warming impacts on today's Sierra Nevada snowpack and flood risk. Geophysical Research Letters 45 (12): 6215-6222. https://doi.org/10.1029/2018GL077432.

Keeley, J.E., and H.D. Safford. 2016. Fire as an ecosystem process. In Ecosystems of California, ed. H. Mooney and E. Zavaleta, 27-45. Oakland: University of California Press.

Knapp, E.E., and J.E. Keeley. 2006. Heterogeneity in fire severity within early season and late season prescribed burns in a mixed-conifer forest. International Journal of Wildland Fire 15 (1): 37-45. https://doi.org/10.1071/ WF04068. 
Knapp, E.E., J.E. Keeley, E.A. Ballenger, and T.J. Brennan. 2005. Fuel reduction and coarse woody debris dynamics with early season and late season prescribed fire in a Sierra Nevada mixed conifer forest. Forest Ecology and Management 208 (1-3): 383-397. https://doi.org/10.1016/j.foreco.2005.01.016.

Knapp, E.E., J.M. Varner, M.D. Busse, C.N. Skinner, and C.J. Shestak. 2011. Behaviour and effects of prescribed fire in masticated fuelbeds. International Journal of Wildland Fire 20 (8): 932-945. https://doi.org/10.1071/WF10110.

Kobziar, L.N., J.R. McBride, and S. Stephens. 2009. The efficacy of fire and fuels reduction treatments in a Sierra Nevada pine plantation. International Journal of Wildland Fire 18 (7): 791-801. https://doi.org/10.1071/WF06097.

Levine, J.I., B.C. Collins, Z.L. Steel, P. de Valpine, and S.L. Stephens. In Press. Highseverity fire incidence higher both on and near industrially managed forests. Frontiers in Ecology and the Environment.

Levine, J.I., B.C. Collins, R.A. York, D.E. Foster, D.L. Fry, and S.L. Stephens. 2020. Forest stand and site characteristics influence fuel consumption in repeat prescribed burns. International Journal of Wildland Fire 29 (2): 148-159. https://doi.org/10.1071/WF19043.

Lyons-Tinsley, C., and D.L. Peterson. 2012. Surface fuel treatments in young, regenerating stands affect wildfire severity in a mixed conifer forest, eastside Cascade Range, Washington, USA. Forest Ecology and Management 270: $117-$ 125. https://doi.org/10.1016/j.foreco.2011.04.016

McLeod, Al. 2011. Kendall: Kendall rank correlation and Mann-Kendall trend test. $R$ package version 2.2. https://CRAN.R-project.org/package=Kendall.

Mitchell, R.J., J.K. Heirs, J. O'Brien, and G. Starr. 2009. Ecological forestry in the southeast: Understanding ecology of fuels. Journal of Forestry 107: 391-397.

North, M., B.M. Collins, and S. Stephens. 2012. Using fire to increase the scale, benefits, and future maintenance of fuels treatments. Journal of Forestry 110 (7): 392-401. https://doi.org/10.5849/jof.12-021.

North, M., J. Stevens, D. Greene, M. Coppoletta, E. Knapp, A. Latimer, C. Restaino, R. Tompkins, K. Welch, R. York, D. Young, J. Axelson, T. Buckley, B. Estes, R. Hager, J. Long, M. Meyer, S. Ostoja, H. Safford, K. Shive, C. Tubbesing, H. Vice, D. Walsh, C. Werner, and P. Wyrsch. 2019. Tamm Review: Reforestation for resilience in dry western U.S. forests. Forest Ecology and Management 432 209-224. https://doi.org/10.1016/j.foreco.2018.09.007.

Quinn-Davidson, L., and J.M. Varner. 2012. Impediments to prescribed fire across agency, landscape and manager: An example from northern California. International Journal of Wildland Fire 21: 210-218.

R Core Team. 2020. R: A language and environment for statistical computing. Vienna: R Foundation for Statistical Computing.

Reiner, A.L., N.M. Valliant, and S.N. Dailey. 2012. Mastication and prescribed fire influences on tree mortality and predicted fire behavior in ponderosa pine. Western Journal of Applied Forestry 27 (1): 36-41. https://doi.org/10.1093/wja f/27.1.36.

Schultz, C.A., S.M. McCaffrey, and H.R. Huber-Stearns. 2019. Policy barriers and opportunities for prescribed fire application in the western United States. International Journal of Wildland Fire 28 (11): 874-884. https://doi.org/10.1 071/WF19040.

Seymour, R.S., A.S. White, and P.G. deMaynadier. 2002. Natural disturbance regimes in northeastern North America - evaluating silvicultural systems using natural scales and frequencies. Forest Ecology and Management 155 (13): 357-367. https://doi.org/10.1016/S0378-1127(01)00572-2.

Sprugel, D.G., T.M. Hinckley, and W. Schaap. 1991. The theory and practice of branch autonomy. Annual Review of Ecology and Systematics 22 (1): 309-334. https://doi.org/10.1146/annurev.es.22.110191.001521.

Starrs, C.F., V. Butsic, C. Stephens, and W. Stewart. 2018. The impact of ownership, firefighting, and reserve status on fire probability in California. Environmental Research Letters 13 (3): 1-11. https://doi.org/10.1088/1748-9326/aaaad1.

Stephens, C.W., and R.A. York. 2017. An evaluation of stand age as a factor of mastication efficiency and effectiveness in the Central Sierra Nevada, California. Northwest Science 91 (4): 389-398. https://doi.org/10.3955/046.091.0408.

Stephens, S.L., B.M. Collins, and G. Roller. 2012. Fuel treatment longevity in a Sierra Nevada mixed conifer forest. Forest Ecology and Management 285: 204-212. https://doi.org/10.1016/j.foreco.2012.08.030.

Stephens, S.L., and J.M. Moghaddas. 2005a. Silvicultural and reserve impacts on potential fire behavior and forest conservation: Twenty-five years of experience from Sierra Nevada mixed conifer forests. Biological Conservation 125 (3): 369-379. https://doi.org/10.1016/j.biocon.2005.04.007.

Stephens, S.L., and J.M. Moghaddas. 2005b. Experimental fuel treatment impacts on forest structure, potential fire behavior, and predicted tree mortality in a California mixed conifer forest. Forest Ecology and Management 215 (1-3): 21 36. https://doi.org/10.1016/j.foreco.2005.03.070.
Stewart, W., R. Standiford, S. Kocher, and J. Webster. In Press. In Reforestation practices for conifers in California, ed. W.C. Stewart. Davis: University of California Agriculture and Natural Resources https://www.fvmc.org/.

Striplin, R., S.A. McAfee, H.D. Safford, and M.J. Papa. 2020. Retrospective analysis of burn windows for fire and fuels management: an example from the Lake Tahoe Basin, California, USA. Fire Ecology 16 (1): 13. https://doi.org/10.1186/ s42408-020-00071-3.

Thompson, J.R., T.A. Spies, and K.A. Olsen. 2011. Canopy damage to conifer plantations within a large mixed-severity wildfire varies with stand age. Forest Ecology and Management 262 (3): 355-360. https://doi.org/10.1016/j.foreco.2011.04.001.

Tibshirani, R. 1996. Regression shrinkage and selection via the lasso. Journal of the Royal Statistical Society. Series B (methodological). Wiley 58 (1): 267-288.

USDA Forest Service, Forest Inventory and Analysis Program. 2021. Forest Inventory EVALIDator web-application Version 1.8.0.01. St. Paul: U.S. Department of Agriculture, Forest Service, Northern Research Station Available only on internet: http://apps.fs.usda.gov/Evalidator/evalidator.jsp.

Van Wagner, C.E. 1977. Conditions for the start and spread of crown fire. Canadian Journal of Forest Research 7 (1): 23-24. https://doi.org/10.1139/x77-004.

van Wagtendonk, J.W., J.M. Benedict, and W.M. Sydoriak. 1998. Fuel bed characteristics of Sierra Nevadaconifers. Western Journal of Applied Forestry 13 (3): 73-84. https://doi.org/10.1093/wjaf/13.3.73.

Weatherspoon, P.C., and J. Mclver. 2000. A national study of the consequences of fire and fire surrogate treatments, 114. Redding: USDA Forest Service Pacific Southwest Research Station http://www.fs.fed.us/ffs/execsumm-4-17-00.

Westfall, J.A., and C.W. Woodall. 2007. Measurement repeatability of a large-scale inventory of forest fuels. Forest Ecology and Management 253 (1-3): 171-176. https://doi.org/10.1016/j.foreco.2007.07.014

Wooley, T., K.C. Shaw, L.M. Ganio, and S. Fitzgerald. 2012. A review of logistic regression models used to predict post-fire tree mortality of western North American conifers. International Journal of Wildland Fire 21 (1): 1-35. https:// doi.org/10.1071/WF09039.

Yang, Y, H Zou and S Bhatnagar 2020. gglasso: group lasso penalized learning using a unified BMD algorithm. R package version 1.5. https://CRAN.R-project. org $/$ package $=$ gglasso.

York, R.A., J. Levine, D. Foster, S. Stephens, and B.M. Collins. In Press. Silviculture can facilitate repeat prescribed burn programs. California Agriculture.

York, R.A., H. Noble, L. Quinn-Davidson, and J.J. Battles. 2021. Pyrosilviculture: Combining prescribed fire with gap-based silviculture in mixed-conifer forests of the Sierra Nevada. Canadian Journal of Forest Research 51 (6): 1-11. https://doi.org/10.1139/cjfr-2020-0337.

York, R.A., A. Roughton, R. Tompkins, and S. Kocher. 2020. Burn permits need to facilitate - not prevent- "good fire" in California. California Agriculture 74 (2) 62-66. https://doi.org/10.3733/ca.2020a0014.

Zald, H., and C. Dunn. 2018. Severe fire weather and intensive forest management increase fire severity in a multi-ownership landscape. Ecological Applications 28 (4): 1068-1080. https://doi.org/10.1002/eap.1710.

Zhang, J., K.A. Finley, E.E. Knapp, 2019. Resilience of a ponderosa pine plantation to a backfiring operation during a mid-summer wildfire. International Journal of Wildland Fire 28 (12): 981-992. https://doi.org/10.1071/WF19033.

\section{Publisher's Note}

Springer Nature remains neutral with regard to jurisdictional claims in published maps and institutional affiliations.

\section{Submit your manuscript to a SpringerOpen ${ }^{\circ}$ journal and benefit from:}

- Convenient online submission

Rigorous peer review

- Open access: articles freely available online

High visibility within the field

- Retaining the copyright to your article

Submit your next manuscript at $\boldsymbol{\sim}$ springeropen.com 